\title{
BREXIT DEAL AND THE EUROPEAN UNION: PROSPECTS \& CONCERNS
}

\author{
Barirah Butt \\ Research Scholar \\ Area Study Centre for Europe, University of Karachi \\ barirah.jugnu@gmail.com \\ Sardar Danish Zaman \\ Researcher \\ Federal Urdu University for Arts Science and Technology \\ danishzaman49@gmail.com
}

\begin{abstract}
The approach to Brexit in the current political dilemma is challengeable for the seekers who want to understand the problem with clarity and perceptibility with the very nature of the European politics. It's under process of becoming coherent and unprecedented in terms of its consequences. Although the opening and ending of the curtain of the European theatre has always been spectacular for its peoples and to the peoples of nearby continents connected to it by a vicarious cycle and in an extended perspective to the rest of the world, but this time the actors are emerging with a new play with a new set of performances. This research is tend to apply the analytical and argumentative approach for the issue in consideration to take into account the different perspectives of the problem in order to perceive and suggest the divergent possibilities involved in a particular issue not only for the EU members but also for other powers. Explained in it are the factors that at first provide impetus for integration despite the presence of the disintegrating elements at the first place, and then the consideration of
\end{abstract}




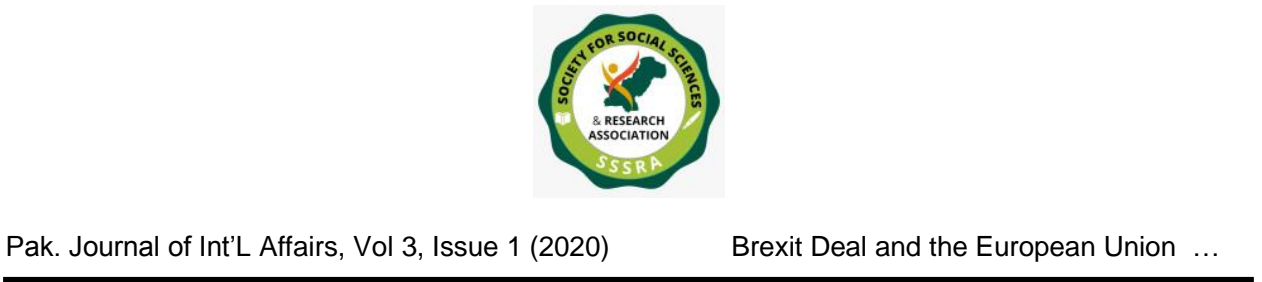

emerging politics of preferences, evolved with a passage of time, and let those disintegrating forces overcome.

\section{KEYWORDS}

Democratic Values, Populism, Referendum, Immigrants, Coalition Government, European Single Market.

\section{INTRODUCTION}

The act of Brexit from European Union has evolved with time in a long period of uncertainty, tension, suppression and anxiety. What citizens of the United Kingdom felt and expressed in the Referendum was actually an expression that has been widely spread in the West. Brexit is the decision of the people and the manifestation of struggle by the masses of the UK against that unpleasant structure. The departure of Britten from EU is a complex and challenging project in a globalized world. It take back to the era of 70s when it was used to call the 'Sick man of Europe'. 'It's stagnating national economy after the Great Depression of 1970s with a malign combination of high inflation, unemployment, low productivity, and industrial rest' affected its preferential choices regarding the joining of the European Union, then, European economic community (EEC). (Clarke, Goodwin \& Whiteley, 2017: 2). Its economic crisis was intensified with high Inflation, Unemployment and under paid employment due to the oil crisis of 1973 which deeply affected the conceptualization of a regulatory authority that can preserve the British economy by framing out a transitionary oil policy. It was also accepted at the time that the plans that would have truly helped Britain prevent or mitigate the 1973 crisis would have required international cooperation and thus remained outside the sole responsibility of the Britain'(Kuiken, 2014: 27). These events led UK to strengthen the role of the European Union and turn it in to a strong regional power but the increasing economic disparities between the Northern and the Southern member states remained a challenge. Some scholars argued that the exclusion of Greece, strengthened the Eurozone because it controlled the economic differences within the European Monetary Union (Vollaard, 2018: 1). 


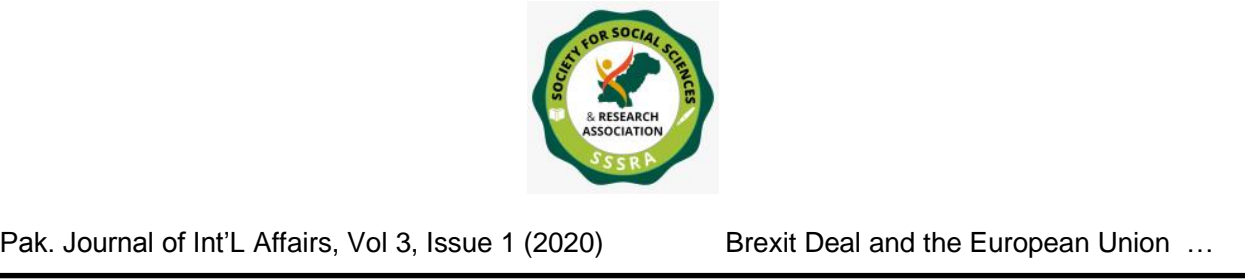

\section{EUROPEAN UNION}

European Union is an intergovernmental transnational regional

organization which has a history of series of treaties lasted for 4 decades before the formal creation of EU. It was started 75 years ago when BENELUX was founded on Sep 1944. It was a politico economic union between three close boundary states of Europe which was enforced in 1958. It was based on the principles of free trade area among three nations, Belgium, Netherland and Luxemburg. Winston Churchill was the first European leader called to build a united states of Europe in order to achieve economic security" in his speech on September 19, 1944 (Pinder \& Usherwood, 2013: 27).

A regional organization created by the merger of European Coal and Steel Community 1952, European Atomic Energy Community 1958 and European Economic Community which was created by the Treaty of Rome in 1957. EEC was renamed as European Community in 1993 now a part of EU. European Defense Community signed by six European governments but ratified by four due to strong opposition in France which remained till 1990. EDC played a major role in terms of collective security subsequently another major development was EFTA formed in 1960 (Egan, Nugent, \& Paterson, 2018: 149). Since 1960s European Community grew its geographical scope up to 28 countries. Since 1974 the European council of the governments develop European Parliament gained in power in the matters of community. In1979 European Monitory System was established later reshaped in Monitory union. Treaties which play key role in forming EU include Single European Act 1987, Maastricht Treaty 1993, Amsterdam Treaty 1999 Nice Treaty 2002 and Lisbon Treaty 2009.European Union now operate on the basis of TEU and TFEU (Pinder \& Usherwood, 2013: 35).

With the successful 3 decades' history of achievements in economic security some countries are yet in a row to get membership of European union such as Croatia, Turkey, Balkan states and Russia lobbing for future membership. European Union was formally established on the basis of TEU in 1993 and Great Britain accept the treaty in august and in 


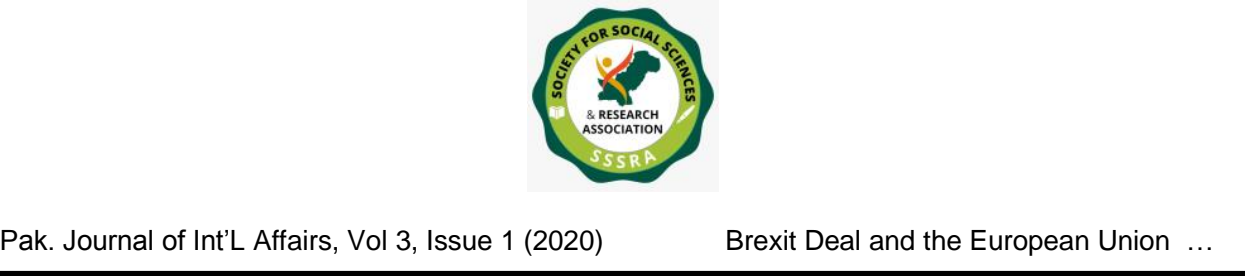

December 13 council approved EEA. The recession of 2007-2008 and Euro crisis 2010-2015 exposed flaws in Eurozone administrative infrastructure particularly hit Britain with double dip recession and unemployment lasted till 2013 (Cabral, Gonçalves, \& Rodrigues, 2017: 25). A dramatic attempt of GREXIT give lesson for U.K that no single country can dictate on their own terms.

\section{BRITAIN AND THE EUROPEAN UNION}

The procedure of Britain joining the European Union has manifolds. The concernment of the idea of European integration was a by-product of the Second World War that transformed European powers to a second rate power on the world stage. The debate of institutionalizing a federating unit in Europe had long been developed in the inter-war period too, and the control of a supranational body above the European nations, had also been discussed before, but all these ideas only got momentum in the 1950s, when the establishment of the European Coal and Steel Community (ECSC) in 1951, and in the later part, the formation of the European Economic Community (EEC) in 1957 brought the idea in reality. The realization of the devastating condition of the states' infrastructure and economy led the path for the making of a coalition body of the Europe, which would have driven by the same interests, threats and future challenges. The attitude of Britain even at that time was not very convincing for union because it was remained a colonizer for more than a century, and didn't want to associate itself with any kind of resource pooling and it perceived NATO would sufficient for its security concerns. It is the country of island that not even comprehends itself a part of the European continent. It didn't want to be part of the union neither it became the member of European Defense Community in 1952. It was the Suez Canal crisis of 1956 that convinced it about the importance of the European Union and realized that alone it has no say or standing in the post-world war II economic structures. The realization of power dependency and the American agenda of pursuing its own interests in the European region proved Britain the need of a unified role to handle the regional challenges and securing their utmost interests. 


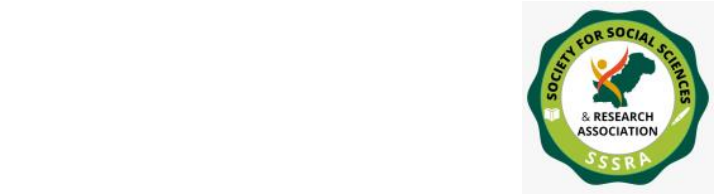

Britain has a long history of democratic values that was also a leading factor then, in the joining, and now, in the departing from the European Union. Their people never tend to compromise on substandard democracy or a supranational body that confronts or restrain their control over their internal issues or regulate their economy by influencing their choices by legally binding monetary structures and oblige them to certain laws. They had fought a long struggle of freedom to get this power transfer to the lower middle class. A long process of the devolution of power from the crown to the ordinary man, which was derived from the Westminster system of parliament, is an achievement they never want to compromise. The waves of populism under the neoliberals' policies in Europe are also the demonstration of power loosening from the hands of commoners.

\section{BREXIT}

"A blend of "Britain" and "exit", the word was coined by former lawyer Peter Wilding four years before the vote for the UK to leave the European Union took place' (Lawrence, 2019). The term indicates Britain's departure from the European Union that was owed to conclude in the two year process after triggering Article 50 of the Lisbon Treaty. According to Article 50, clause A; 'Any Member State may decide to withdraw from the union in accordance with its own constitutional requirements'. (Institute for Government. (2019). Further elaborated in clause C; 'The treaties shall cease to apply to the state in question from the date of entry into force of the withdrawal agreement or, failing that, two years after the negotiation referred to in paragraph 2, unless the European Council, in agreement with the Member State concerned, unanimously decides to extend this period.'(ibid.) The United Kingdom of Britain under the premiership of the Conservative party leader David Cameron opted a referendum 'on June $23^{\text {rd }}, 2016$, which resulted in the majority of $51.9 \%$ or 17.4 million people voted to leave the European Union with a contrasting opposition of $48.1 \%$ or 16.1 million people who voted to Remain in the union. More than a million people didn't cast their vote.'(Will, 2019). The careful examining of the vote bank of the four island nations comprising the United Kingdom is compulsory in order to comprehend the whole picture of exit. ' $53.4 \%$ of English voters supported Brexit, compared to just $38.0 \%$ of Scottish 


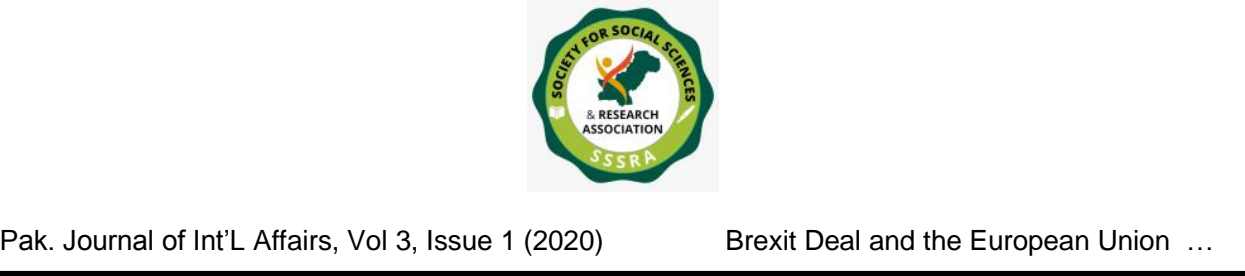

voters. In Wales, $52.5 \%$ people, while in Northern Ireland $44 \%$ persons voted for leave. (Ibid). If Referendum were based only on Wales, Scotland and Northern Ireland voting results, the situation could've been different in favor of Remain. Here the England as the most populous island turned the cards against the merger.

\section{CONFLICTING PREFERENCES OF THE POLITICAL PARTIES}

The overall calculated figure of Referendum and the result of the December, 12, 2019 elections shocked almost all the perceptible sectors of the country; the academia, political scientists, economists, media persons, Parliamentarians, and the political parties of Britain. Since the referendum the problem of withdrawing from the union has become ever more complex and serious. The division among the leading political parties namely the Conservatives and the Labours along with the other parties are standing on the two edges of one problem and being stuck there with the divergent interests of the upper and the lower-middle classes with different perceived solutions.

The Conservatives want a clean exit, and their decision is further strengthened by 'The Brexit Party's campaign; "Leave means Leave", led by the post UKIP leader Nigel Farage' (Farage, 2019). While the Liberal Democrats want the revocation of Article 50 and want another Referendum for Remain. Here the main opposition party the Labours wants to secure a sensible Brexit deal, and they too want a second referendum on exit. The labour party has the support of the Greens and the Scotland National Party (SNP) who demand the cancellation of the Brexit and securing a second Referendum on Remaining.

Above all, the over-whelming victory of the Boris Johnson by securing ' 365 votes (326 votes were required to form a majority government), securing 47 additional votes from the opposition parties' mandate' (BBC NEWS: Election2019). This victory tends to end the deadlock between the political parties which directly influences the people of the UK. Boris Johnson in his victory speech declares the process of exit be executed on $31^{\text {st }}$ of January after the Christmas, that is on Wednesday, December, 25, 2019. He emphasized on leaving the European Union and 'taking back 


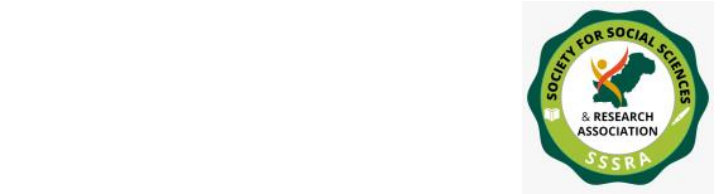

control of our laws, borders, money, our trade, immigration system, delivering on the democratic mandate of the people' (The Guardian, 2019). While the supporter of a second referendum, the Labour party has secured 203 seats from its hub Islington North constituency, while it lost 59 seats. 'Mr. Corbyn himself received 34,603 votes in Islington North; his party suffered a massive defeat as the Tories secured a majority. $\mathrm{He}$ announced that he won't lead the party in any future general election campaign' (Clarke, 2019). Keeping the things as they are 'the SNP secured 48 seats, the liberal democrats 11 seats, the DUP gained 8 seats and the other party preserving 15 seats' (BBC NEWS: Election2019).

After more than four decades, Brexit means the re-shuffling of the whole system, from trade policies to Immigrant policies, quitting European Union Court of Justice laws to framing and adopting British laws, leaving EU taxation policies to free trade deals, and leaving Common Fisheries policies to gain self-control over territorial waters, everything needs a recodification. There are a large no of areas that will need re-legislation. The European Union had made mechanisms of all the important sectors like 'agricultural subsidies, criminal justice measures, environmental standards, and the financial service regulations to nuclear power technology, university student fees to employment law and aviation, things will become difficult to manage in the right direction'(Martill \& Staiger 2018: 01).

\section{CAUSES OF BREXIT COMPLEXITIES}

'Societal debates arise not simply because we are conflictual beings with diverse values, traditions and beliefs but also because we are suspicious of the possibility of universal rational compromises' (Zabala, 2017). From a pragmatic point of view, when Britain joined the European Union, the political scene of Europe was entirely different. Six initial members that include Benelux countries; Belgium, Netherlands, Luxembourg along France, Italy and West Germany pooled their energy resources, mainly coal, steel, and iron to turn the tide of the war raged economies into a progressively integrated whole. With its further development into the European Economic Community was a lucrative offer for the United 


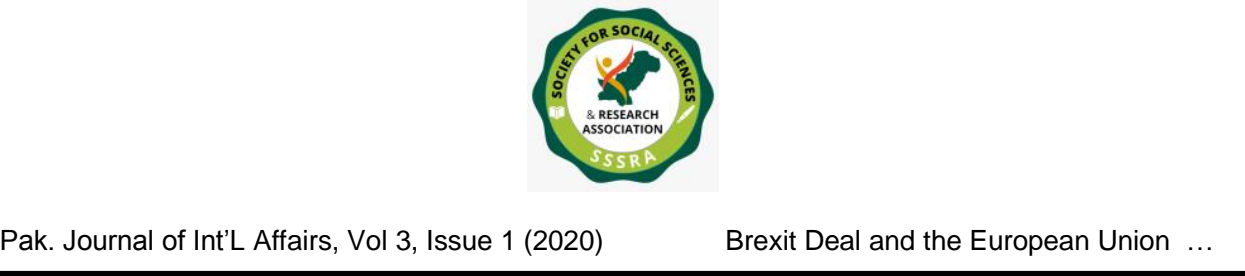

Kingdom low growth economy. The benefits it enjoyed being part of the union were gradually changed into burden when a series of enlargement start happening and the number of states jumped to 28 till 2013.

'Beginning in 2008, the continent had been hit hard by the great Recession and a major debt crisis that was especially severe in southern EU member states such as Greece, Spain and Portugal. In sharp contrast to the picture that had confronted Prime Minister Harold Wilson in 1975, Cameron now talked of a continent that was blighted by lack of competitiveness, excessive regulation, a deficit of democratic accountability, and that had taken too many powers away from individual members.' (Clarke, Goodwin \& Whittely, 2019: 26)

\section{AMERICAN INTERESTS IN THE EUROPEAN REGION}

'Not many people know that the EU was given a decisive push into existence in the early 1950 s by the CIA. After that, the United States has always been careful to promote Atlanticist, pro-European community governments in every member state.' (Brexit: European Union, American Empire: 05). A single market Europe is the most favorable condition for the persuasion of the American interests in the region.

The victory of Donald Trump in the 2016 elections is a major setback in the rise of the populism sentiments. His utterly distinctive language for the Americans and for the outsiders (Muslim and Mexicans), the foreigners whom he assumed a threat for the American identity and their policy of Protectionism for its cure further clarified the state of mind a major group of people in the western democracy behold. There is a shift of stance between the Obama Government and the Trump administration. Former president has warned the United Kingdom in the case of Brexit that 'the U.K would be at the "back of the queue" in any trade deal with the US if the country chooses to leave the EU' (Asthana \& Mason, 2016). He refused the happening of US-UK trade deal in the future for what they are interested in, is the trade agreement done with a single body of the European Union. On the contrary note, the world witnessed Donald Trump positioning a central role in offering the post-Brexit trade deals on which the opposition leaders of the UK has serious concerns. According to 


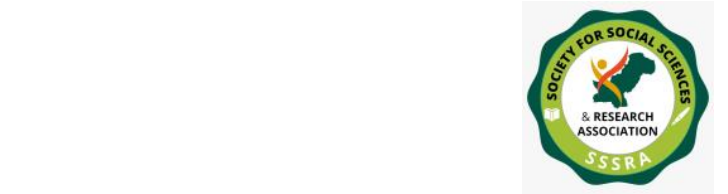

their viewpoint, this would lead to the American corporations dominating our infrastructure and will hinder independent economic policies. The idea of American political conglomeration in British polices would influence and in the later, dictate the brutish Capitalist norms of their society into our working sector. It will not only bridge the gaps of economies but also compromise the standards of housing, health care services, workers' rights and infrastructures.

\section{A NEGLECTED FACTOR OF RELIGION}

There is also a role that religion plays in directing the core values of the people. They are obliged to fulfill certain religious jurisprudence which is the core of their living codes. It has been generally neglected that 'Anglicans are more likely to vote 'Leave' than other religions. As far as we can tell, this is due to both historical suspicion of transnational institutions (not least the Catholic Church) and the close identification of the Church of England with national identity' (Menon, Wager, 2019: 04). This association hinders especially the British Catholics to remain part of the EU.

Jesuits (a Roman Catholic priest, who is member of the Jesuit society) have a mix say for Brexit. In a conversation, Bishop Hudsen pointed out that 'Europe in not just an economic unity but more importantly a human project' (Jesuits in Britain, 2017) and the prisoners who are serving sentence is also a matter of human dignity that can be humiliated in a post Brexit scenario. They make it a point to give the prisoner the right to decide in which country the convicted want to serve the sentence. Most of the Roman Catholics prisoners are jailed in the European Union states. Bishop Burns while reflecting on his experience shared that 'an exchange of ideas and breaks down prejudices is something precious and should never be lost... closing borders never aligns to the interests of Church, which is always universal in its outlook.' (Ibid.). He described Europe as a 'huge Vineyard of Culture'. (Ibid.). Whereas, Paul Garner of the Biblical Creation Trust, strongly advocated the leave position and remained with his stance that the EU has proved bad for the United Kingdom. Evangelic like a huge no of the masses of UK are uncertain about the impacts that 


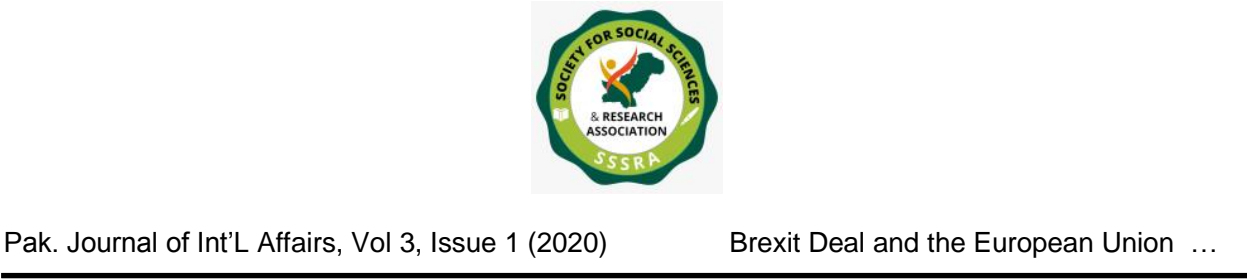

Brexit will bring about. What they concern more is 'the removal of the mutual rights of free movement which are likely to make it harder for the citizens to serve as missionaries in some European countries' (Chitwood, 2019).

Among the negative impacts of Brexit in compliance to Catholics discomfort, one is the hindrance for the people of the other regions, as Eastern Europe, Middle East, Central Asia; for they find it harder to come to UK and stay there for work purposes. This obstruction, which will priests will face as well will affect the circulation of the divine message as missionaries will have to fulfill border requirements and free movement will no longer be permissible.

There is a growing unrest in the ethnic minorities as well who feel themselves alienated and less privileged in terms of voting patterns and thereby voted to leave. The discrimination is still present in the system of voting that empowers some by giving extra voting rights over others. These deep-rooted differences are now re-surfacing and dismantling the very structure of the European Union.

The problem is also connected to the unwritten nature of the British constitution that confronts British people lock handed to cope the inexperienced challenges. This absurdity in defining laws over exit caused the politicians rambling on the issue for three years. Its unwritten nature can pose threats for the democratic integrity as well as create tensions. "We have airy principles. But, ultimately, our "unwritten" constitution means that in times of crisis, such as now, anyone can choose a principle to justify their arguments', As Groucho Marx may have said, "these are my principles, and if you don't like them ... well, I have others" (Wagner, 2019).

\section{THE EMERGENCE OF THE BREXIT PARTY}

The Brexit party came out in 2019 under the past UKIP leader Nigel Farage after the failure of the Prime Minister Theresa May to deliver the Brexit process on its original departure date which was March 2019. It was founded by the business tycoon Richard Tice and business consultant John 


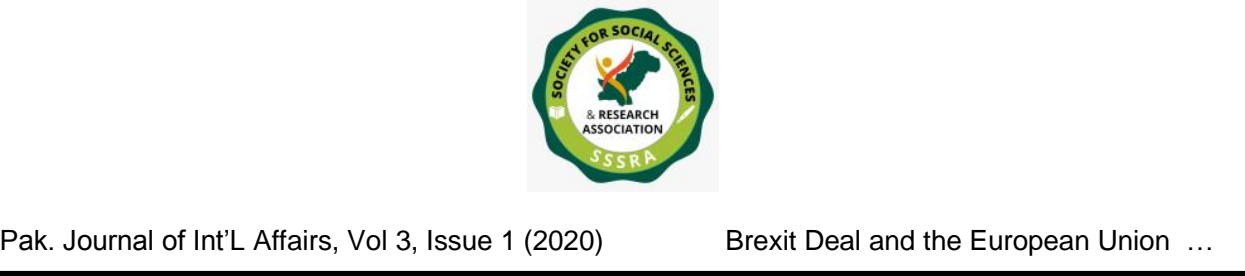

Longworth. Now when the exit is postponed because of the unsuccessful process of the Britain trade deal with the European Union, mainly concerned with the unconcerned attitude of the union regarding the agreement on the customary union, uncertain economic situation is prevalent in Britain after Brexit.

\section{POPULISM}

Santiago Zabala has rightly pointed out the compromises that the neoliberalism has entangled common men whose real choices have been blurred and overcome it with an artificial framework of politics, mainly emasculates the elite class' interests and embroils peasantry real demands. This blurriness is vaporizing the sense of democracy from the ordinary people and the working class of the West. The whole idea of the devolution of power to the lower classes and the struggle that has been struggled is being shattering now to bottom up.

One of the factors that play an important role behind Brexit is the right and the left wing Populism, a concept towered in the 1990s under different notions of Political Correctness, Inclusivity and gender discrimination. The leading parties of the UK, mainly the Conservatives and the Labor, have adapted the financial criteria that caused them 'their popular support through their acceptance of the demands of financial capitalism' (Aljazeera, 2017). This also leads mistrust between the people and their political representatives which can be viewed in the results of the December, 12, 2019 elections. The majority of the voters voted to leave, as they no longer feel secured under the current political scenario and break the shackles of a system that stops representing the different levels and classes of the British society.

\section{FUTURE CONSEQUENCES OF BREXIT FOR UK \& EU}

Brexiteers believed that after leaving Eurozone Britain would boast their economy making their country wealthy again because they will free from any state interference or community and they would get their former economic status. The free trade in future will help even if other countries impose World Trade Organization taxes but the British impose no tariffs 


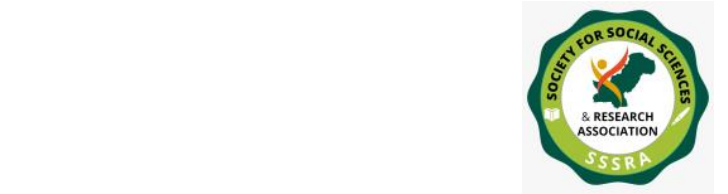

in return which sounds like a fairy tale write by Brexiteers (Dorling \&Tomlinson, 2000:154). In 2018, it was reported by the statistics portal Statista claim on the basis of their study China got 34\%, South Korea 22\% and Japan $21 \%$ The EU, which included Britain, and to which was added Norway, took only $11 \%$ which means that there is less chances of growing British economy after leaving Union (Ibid, 160). As the Governor of the Bank of England said, due to Brexit banking sector cut 10,000 in day one, unless there is a deal that makes it appear as if Brexit never happened over 200,000 banking jobs could go (Ibid, 161). Overcrowding Immigration, national sovereignty and the costs of membership of union are major causes on which all the campaign relay on but it is a fact that immigrants play a key role in doing odd jobs and cultural diversity whereas cost of membership UK pay back in terms of FTA after exit from community (Antoniolli , Bonatti \& Ruzza, 2019: 106). Union exit would mean third-country rules will apply to UK for access to the single market until and unless another agreement is found. Brexit would mean EU's economy would also suffer due to Britain availability would also decrease and its expertise would no longer with union (Cabral, Goncalves \& Rodrigues, and 2017: 391). It would discourage transnational investment entrepreneur would hesitate to invest their shares in any other member nation international trade conventions, Union could provide for most favorite nation (MFN) treatment to England in order to avoid economic setback and for sustainable development (Ibid, 394).

Exit would also boost the sentiments of other citizens of member nations to follow English model to deal with Union, it also rises question on political and administrative structure of union what flaws which enable a country to think about their own personal interest rather than union also an exit of any country would blackmail the union to address the personal interest of their own. There are certain banks and their branches of Union which operates from UK which need more capital for their business in the premises of UK such banks will face some hurdles in terms of converting their present administrative structure from branches to subsidiaries or start their operations separately (Cabral, Goncalves \& Rodrigues, 2017: 405). 


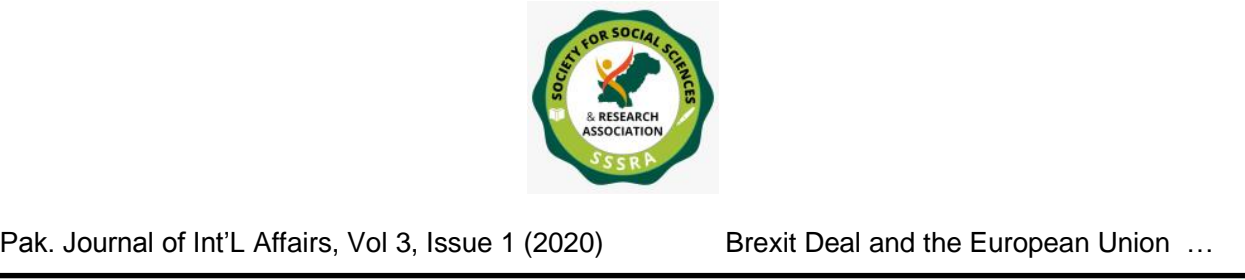

On the other hand the future consequences of Brexit can be severe for Britain and it could face a severe economic crisis once again without securing a reasonable deal with the Union and could be a subject of isolation from the European region, or could fail to secure the Most Favorite Nation (MFN) status. While on the other side, the withdrawal of a strong regional actor can further exacerbate the situation for the union, and motivate the remaining member states to use the same authority on the basis of their conflicting point. The American economic assistance and the trade deals boosted the British economy but also remain contagious with its own kind of capitalistic susceptibilities. Brexit will set an example for both sides and some firm post-exit measures, whether it's the restructuring of the Article 50 that is a gateway of exit or the loosening of the European Commission's power by limiting its role in the domestic politics and making amendments in the confederated body of the union by the member states.

\section{CONCLUSION}

The emergence of EU as a single market actor was an attractive and comparatively better deal for the European states and for the other regional bureaucratic powers whose interests were posed with an unhindered design of access to the European markets. In the presence of Various International governing bodies, like, Common Wealth, NATO, WEU, ECSC, EURATOM, EFTA, EEA, they opted for the European Union. The development after five decades start reversing because of the very capabilities that have turned into incapacity before the storm of economic crisis and political and monetary discrepancies.

In the case of Britain, its exclusion from the Union is a failure of the intellectual class' argument that didn't resonate the voices of the large segment of the British society. The mismanagement and untimely efforts of reconciliation further exacerbate the situation and rose anger in the old men who were facing pension cuts, or the lower working class fellows outside the London enduring calamities, and the masses who are feeling oppressed in this globalised framework on the Union. The incapacity of the European leaders to fill the ever increasing gap between the elite and 


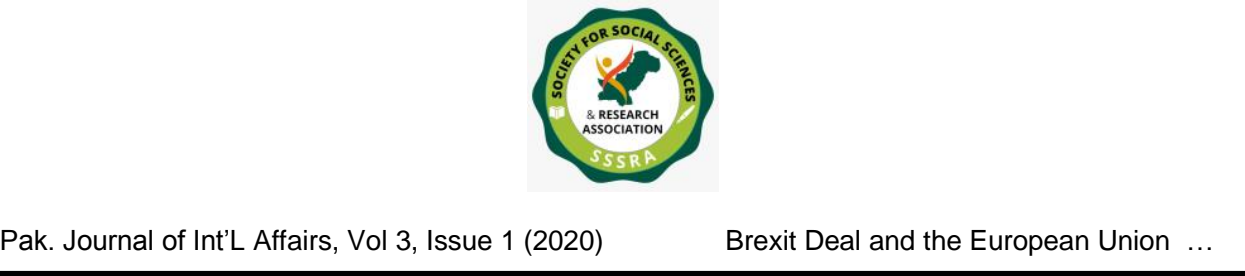

the working class, and the radicalization of the society with the emerging waves of Populism took the problem to worse. The poor condition of the Health and Social sectors andit's severe financial pressure were the key concerns of the Commoners which proved decisive in the process of separation.

Now, in front of Britain, many challenges are standing now; making a new foreign and security policy and securing trade deals with the European states and the America would be essential in this regard. The body of the European Union will also suffer the loss of a powerful ally who military, navy and intelligence expertise stands distinct in comparison with other member states. The strategic location of Britain was also vital for the Euro-Atlantic relationship. Now, new allies are to be formed. A plethora of issues are confronted and their solution requires a wider understanding of the multi-ethnic diverse communities of the UK. It is crucial to resolve the issues to on human right standards, especially the problem of refugees, and the question of the use of smart power. Brexit is an exemplar for Greece whose separation from the Union is largely advocated from the Union itself. The rising uncertainty in Greece since after 2010 has mainly grown because of the expansion of the welfare system in Greek that started in the 1980s and stood still because of the austerity measures adapted to reform the Greek budget whose byproduct was the reduction in facilities in the health care and pension sectors. The dissatisfaction has grown more by the EU migration crisis on social and cultural levels. This has created a same like situation in Britain where a large number of masses turned against the Union procedures. The voices of disintegration can be heard in the Netherlands too which is the next expected spot of Referendum on leave. Rising Euroscepticism and the realization of the lessening of power calls for a 'Nexit', and the restoration of Dutch power and wealth.

This situation is empty of a speed breaker, and a list of countries is stood by to practice the same Referendum in their states. Where Populist fraction is gaining strength and the radicalization in decisions is becoming a prevalent factor. People all over the world want to retain their identity, no matter what. This identity crisis emerges when your start becoming invisible in the rush of the world. Your distinctive identity, which is an 
outcome of your centuries of struggle, and the principles, concerns and fears, your unique way of coming out of a crisis, your historical perspectives and keeping all these in mind, your future strategies that you have prepared with a consensus to you particular environment is hard to cut and blur. This is also connected to the eternal wish of living forever or leaving the principles of living behind for the future generation to tread on. This sense of preserving and holding to one's cultural assets directs us toward a deeper human aspect which is again based on insecurities. People want their communities to flourish and don not want in migrants' settlements because they find a connection with the natives which makes them feel comfortable and known among them. Human being, generally as a creation, wants to remain part of the memories.

\section{References}

Aljazeera: Europe; The difference between right and left-wing populism,

https://www.aljazeera.com/indepth/opinion/2017/01/difference-leftwing-populism170112162814894.html. Retrieved: December, 10, 2019.

Antoniolli, Luisa, Bonatti, Luigi, Ruzza, Carlo (2019) Highs and Lows of European Integration: Sixty Years After the Treaty of Rome,Switzerland,Springer.

Asthana, Anushka, \& Mason, Rowena, (2016) The Guardian: Barack Obama: Brexit would put U.K 'back of the queue' for trade talks: https://www.theguardian.com/politics/2016/apr/barack-obama-brexituk-queue-for-trade-talks, Retrieved: December, 14, 2019.

BBC NEWS, Elections 2019: UK Results: Conservatives win majority, bbc.com/news/election-2019-50776671, Retrieved on December, 14, 2019 
Brexit: European Union, American Empire, file:///D:/Brexit\%20books/Brexit\%20European\%20Union, \%20American\%20Empire\%20(\%20PDFDriv e.com\%20).pdf, Retrieved: 12-12-2019).

Cabral, Nazaré da Costa, Gonçalves, José Renato, Rodrigues, Nuno Cunha (2017) After Brexit: Consequences for the European Union, Netherlands: Palgrave Macmillan.

Chitwood, Ken (2019) Christianity Today, British Evangelics Brace for Brexit,

https://www.christianitytoday.com/news/2019/december/british-

evangelicals-brexit-deadline-boris-johnson-vote.html. Retrieved: December, 15, 2019.

Clarke. Emma, Jeremy Corbin speech in full: Labour leader announces plans to step down as party suffers election defeat 2019, https://www.standard.co.uk/news/politics/jeremy-corbyn-speechresignation announcement-a4312571.html, Retrieved on December, 14, 2019).

Clarke, Harold D., Goodwin, Mathew, \& Whiteley, Paul. (2017) Brexit: Why Britain Voted to Leave the European Union, Cambridge: Oxford Cambridge Press.

Dorling, Danny, Tomlinson, Sally (2015) Rule Britannia: Brexit and the end of empire, United Kingdom: Biteback publishing house Egan, Michelle, Nugent, Neil, E. Paterson, William (2018) European Disintegration: A Search for Explanations, Netherlands: Palgrave Macmillan. 
Farage, Nigel (2019) Leave Means Leave, Advisory Board: Our Campaign, leavemeansleave.eu/our-campaign. Retrieved: 22-Nov2019.

Institute for Government. (2019) Brexit Brief: Article 50. Retrieved by: https://www.instituteforgovernment.org.uk/brexit-brief-article-50. Retrieved: 21-Nov 2019.

Jesuits in Britain, The Role of the Catholic Church in U.K-EU Relations, https://www.jesuit.org.uk/role-catholic-church-uk-eurelations. Retrieved: December, 15, 2019.

Jonathan, Kuiken. JSTOR, Caught in Transition: Britain's Oil Policy in the Face of Impending Crisis, 1967-1973. Journal Article: Historical Social Research, Vol. 39, (2014)

Lawrence, Janet (2019) Reuters: Brexit basics: What is Brexit and why does it matter? https//www.reuters.com/article/uk-britain-eu-basicsexplainer/brexit-basics-what-is-brexit-and-why-does-it-matteridUSKBN1WX1WY) Retrieved: 21Nov 2019

Martill, Benjamin \& Staiger, Uta. (2018) Brexit and Beyond: Rethinking the Futures of Europe, London: UCL PRESS.

Menon, Anand \& Wagor, Alan (2019) Brexit and Public Opinion: The U.K in a Changing Europe; Analyzing the Referendum: Brexit and British politics, www.ukandeu.ac.uk/wpcontent/uploads/2018/01/Public-opinion.pdf. Retrieved: 12-12-2019. 
Pinder, Jhon, \& Usherwood, Simon ( $3^{\text {rd }}$ Ed, 2013) The European Union: A very short introduction, United Kingdom: Oxford University Press.

The Guardian, General Elections 2019: 'We Smashed the Roadblock': Boris Johnson election victory speech in full-video, December, 13, Friday, https://www.theguardian.com/politics/video/2019/dec/13/borisjohnson-election-victory-speech-in-full-video. Retrieved on December, 14, 2019.

Vollaard, Hans (2018) European Disintegration: A search for Explanations, New York: Palgrave Macmillan.

Wagner, Adam (2019) New Statesman America: The Brexit crisis shows why the UK finally needs a written constitution, https://www.newstatesman.com/politics/uk/2019/08/brexit-crisis-

shows-why-uk-finally-needs-written-constitution, Retrieved: December, 14, 2019.

Will, Kenton (2019) Brexit, investopedia.com/terms/b/brexiot.asp. Retrieved: 22-Nov-2019

Zabala, Santiago (2017) The difference between right and left-wing Populism: Right-wing Populism evokes fear, left-wing Populism hope, .Aljazeera.

https//www.aljazeera.com/indepth/opinion/2017/01/difference-leftwing-populism-170112162814894.html, Retrieved on December, 14, 2019. 